Social Work

\section{\& Education}

CSW\&E, 2021

УДК 373.5.015.31:176]:[343.85:364.633]

DOI: $10.25128 / 2520-6230.21 .2 .8$.
Мельничук, В. (2021). Взаємодія спеціалістів у процесі надання послуги з патронату. Social Work and Education, Vol. 8, No. 2. pp. 229-243. DOI: $10.25128 / 2520-6230.21 .2 . .8$.

\title{
СОЦАЛЬНА ПРОФІЛАКТИКА
} ЗАЛУЧЕННЯ ПІДЛТКІВ ДО КОМЕРЦЙНОГО СЕКСУ У ЗАКЛАДАХ ЗАГАЛЬНӦ̈
СЕРЕДНЬӦ̈ ОСВІТИ

\author{
Вікторія Мельничук, \\ завідувач сектору соціально- \\ педагогічної роботи відділу \\ наукового та навчально- \\ методичного забезпечення змісту \\ позашкільної освіти та виховної \\ роботи, Державна наукова \\ установа «Інститут модернізації \\ змісту освіти», \\ м. Київ, Україна; \\ m-viki@ukr.net
}

ORCID ID: https://orcid.org/00000002-0144-8654

\section{Cmamyc cmammi:}

Отримано: квітень 27, 2021

1-ше рецензування: травень 2021
Анотація. У статті розглянуто поняття комерційного сексу. Охарактеризовано соціальнопсихологічні критерії, за якими можна виділили «групу ризику» серед підлітків, що можуть бути залученими до комерційного сексу. Означено, що залучення підлітків до комерційного сексу обумовлене великим комплексом взаємообумовлених причин, що визначає необхідність комплексного підходу соціальної профілактики залучення підлітків до комерційного сексу. Розглянуто організацію соціальної профілактики залучення підлітків до комерційного сексу в умовах закладу загальної середньої освіти. Описано результати дослідження щодо обізнаності учасників освітнього процесу щодо залучення підлітків до комерційного сексу. Зазначено, що профілактична робота 3 попередження негативних суспільних явищ, у тому числі i проституції, закладається i проводиться у закладах освіти і в сім'ї. Доведено, що негативне соціальне оточення, складне матеріальне становище, педагогічна занедбаність та інші чинники, які так чи інакше впливають на формування особистості дитини, передбачають застосування особливого підходу та використання нестандартних методів профілактичної роботи. Виявлено необхідність розроблення профілактичної програми, спрямованої на профілактику залучення підлітків до комерційного сексу.

Ключові слова: комерційний секс; підліток; сексуальне насильство; дитяча проституція; 18, соціальна профілактика; заклад загальної середньої освіти; жертва насильства.

Прийнято: травень 30, 2021 


\section{Вступ}

Складна соціально-економічна ситуація в Україні, поглиблення кризового стану одночасно в трьох сферах життєдіяльності - духовній, соціальній та економічній - спричинили глибокі зміни у світосприйнятті і поведінці молоді. Драматизм поглиблення кризового стану всіх сфер життя українського суспільства полягає в тому, що він носить системний характер і значною мірою позначається на психіці та сприяє формуванню девіантної поведінки серед молодого покоління. Особливо згубними є зростання злочинності, розвиток наркоманії та алкоголізму, проституція, втрата високих ідеалів, неоптимістичне сприйняття життя, відчуження від суспільства.

Згідно даних Українського інституту соціальних досліджень ім. О. Яременка, серед жінок, які займаються наданням сексуальних послуг в комерційних цілях, $11 \%$ складали діти у віці від 12 до 15 років і 20\% - у віці від 16 до 17 років (Балакірєва О., Бондар Т., Галустян Ю., 2012).

Згідно з даними біоповедінкових досліджень цього ж Українського інституту соціальних досліджень ім. О. Яременка та ЮНІСЕФ (2013-2014 рр.) серед 123,5 тис. дітей, що належать до груп ризику, і дітей вулиці, кількість дівчат, які надають сексуальні послуги на комерційній основі, склала 5,5 тис., кількість хлопчиків-підлітків, які мали секс з чоловіками, склала 13 тис. (Балакірєва О., Бондар Т., Сазонова Я., Сакович О., 2018).

\section{Аналіз досліджень і публікацій}

Проблема профілактики залучення підлітків до комерційного сексу у школах на сьогоднішній день залишається недостатньо дослідженою. Науковці (зокрема, Н. Заверико, О. Кізь, О. Кікінежді, В. Кравець, Т. Сальнікова та ін.) пріоритетними напрямами дослідження визначають проблеми збереження сексуального та репродуктивного здоров'я підлітків, однак технологічний аспект попередження ризикованої сексуальної поведінки, до якої ми відносимо і комерційний секс, у наукових працях не розроблений.

Тема профілактики негативних явищ $\mathrm{y}$ молодіжному середовищі висвітлювалась такими науковцями як О. Баришполець, А. Капська, К. Левченко, А. Макаренко, В. Оржехівська, І. Трубавіна та ін.); технологій соціальної профілактики (О. Безпалько, Р. Вайнола, В. Лютий та ін.); явища проституції як форми девіантної поведінки неповнолітніх (М. Галагузова, Я. Гілінський, Т. Гурлєва, А. Кнапік та ін.).

Серед сучасних дисертацій особливий інтерес для роботи над темою дослідження становлять праці таких авторів: Л. Ковальчук (соціально-педагогічні умови профілактики торгівлі дітьми); Л. Лінник (соціально-педагогічні засади профілактичної роботи з важковиховуваними підлітками); Н. Фоміна (соціальнопедагогічна діяльність загальноосвітньої школи 3 профілактики девіантної 
поведінки підлітків); О. Швед (сексуальна експлуатація неповнолітніх як соціальне явище: тенденції і шляхи профілактики); А. Шиделко (соціальна профілактика статевої деморалізації неповнолітніх дівчат в Україні та в Польщі) та ін. Власне А. Макаренко, який стояв у витоків технологізації педагогіки, першим створив i апробував техніки дисципліни, розмови 3 вихованцем, самоуправління та покарання. Послідовність та неперервність дій педагога в сукупності з отриманими практичними навичками були систематизовані в певний технологічний процес, який проєктував позитивні якості у підлітків. Звідси випливає, що педагогічна технологія - це строге наукове проєктування і точне відтворення педагогічних дій.

Метою статті $\epsilon$ аналіз результатів дослідження щодо соціальної профілактики залучення підлітків до комерційного сексу у закладах загальної середньої освіти.

\section{Методологія дослідження}

У статті використані теоретичні методи дослідження - узагальнення теоретичних даних, аналіз, порівняння, синтез для визначення факторів, що сприяють залученню підлітків до комерційного сексу; контент-аналіз нормативно-правових документів, систематизація i класифікація науковотеоретичного матеріалу для визначення i характеристики вітчизняних та зарубіжних підходів до організації і здійснення соціальної профілактики залучення підлітків до комерційного сексу; емпіричні - опитування підлітків для визначення наявності та особливостей ризикованої поведінкової практики; анкетування класних керівників закладів загальної середньої освіти та батьків підлітків; методи математичної статистики з метою кількісної обробки даних та визначення статистичної значущості отриманих у ході експерименту результатів.

\section{Основна частина}

Наслідки зростання поширеності проституції i, відповідно, іiі соціальних i медичних ефектів, посилюються слабкою результативністю системи соціального контролю у сфері залучення підлітків до комерційного сексу. Наукова дискусія 3 проблеми контролю проституції в останні роки протікає паралельно 3 теоретичним осмисленням і спробами практичного вирішення цілого ряду інших, пов'язаних із комерційним сексом, проблем - таких як сексуальність і сексуальна поведінка, статеве виховання людини, превенція сексуальної експлуатації.

Діти через свої вікові особливості, беззахисність, нездатність усвідомлювати повною мірою власні дії та вчинки за всіх часів ставали жертвами насильства, незаконної трудової та сексуальної експлуатації. Проте сучасне суспільство із його інформаційними технологіями, розвиненою інфраструктурою дозвілля $\mathrm{i}$ споживання, загальною гедоністичною настановою, з одного боку, та численними 
соціальними негараздами, невирішеними проблемами соціально-економічного забезпечення нужденних верств населення, - 3 іншого, створюють нові можливості для залучення неповнолітніх осіб у секс-індустрію.

Таке складне явище, як проституція, обумовлене великим комплексом взаємообумовлених причин, тому випливає необхідність комплексного підходу до iï профілактики. Це проблема поетапного і цілеспрямованого статевого виховання, формування широкого світогляду, загальної культури особистості, підвищення рівня загальної та спеціальної освіти у дорослого населення, яке впливає на виховання підростаючого покоління, його свідомість та поведінку.

Основними соціально-психологічними критеріями, за якими можна виділили «групу ризику» серед підлітків $є$ :

- соціальне сирітство;

- виховання у неповній або деформованій сім'ї;

- насильство у дитинстві з боку батьків;

- ранній початок статевого життя;

- вживання наркотичних речовин та/або алкоголю;

- дезадаптованість 3 причини відсутності солідарності з моральними нормами суспільства;

- підвищений рівень тривожності;

- схильність уникати людей, спілкування з малою кількістю людей;

- ухиляння від прийняття рішень;

- очікування контрою та прагнення залежності від інших;

- невідповідність між двома аспектами «Я-образу» - знаннями про себе та ставленням до себе;

- нестійка ідентичність (Раделицька I. І., 2019).

Основна профілактична робота щодо попередження негативних суспільних явищ, у тому числі і проституції, закладається і проводиться у закладі освіти і в сім'ї.

При проведенні нашого дослідження, для вивчення чинників, що сприяють поширенню комерційного сексу серед підлітків та розроблення програми профілактичних заходів нами були поставленні наступні завдання:

- виявити можливі причини залучення підлітків до комерційного сексу;

- вивчити рівень поінформованості підлітків щодо ризиків, якими загрожує залучення до комерційного сексу;

- виявити, чи знають учні/учениці про існування даної проблеми;

- з'ясувати особливості психосексуального розвитку у підлітковому віці, 3 метою встановлення терміну початку введення профілактичних заходів;

- визначити рівень довіри, обізнаності щодо організації вільного часу дітей;

- визначити роль школи у статевому вихованні підлітків; 
- виявити, чи готові педагоги до здійснення профілактики залучення підлітків до комерційного сексу.

\section{Результати дослідження}

У 2018-2019 навчальному році нами було проведене дослідження на базі трьох закладів загальної середньої освіти м. Києва. Експеримент охоплював 100 учнів/учениць, 50 батьків та 50 педагогів/педагогинь. Об'єктами дослідження були учні/учениці 8-9 класів, оскільки саме ця вікова група (14-16 років) становить предмет нашого дослідження (підлітки).

Для дослідження окремих показників ризику залучення до комерційно сексу ми розробили авторські анкети.

В ході анкетування, у якому взяли учать 50 вчителів (з них 38 жінок та 12 чоловіків) віком від 24 до 69 років, освітньо-кваліфікаційного рівня спеціаліст (64\%) та магістр (36\%), були запропоновані наступні запитання: «Чи проводите Ви заняття зі статевого виховання учнів/учениць?» на що $15 \%$ опитуваних дали відповідь «так» і $85 \%$ - «ні». «Комерційний секс - це» більшість респондентів (85\%) назвали проституцією, $15 \%$ - назвали відносини, коли один партнер отримує від іншого певні матеріальні блага, як винагороду. «Як ви думаєте, яка ступінь впливу неблагополучних сімей на соціалізацію підлітків?» - 80\% опитаних вважають, що в процесі соціалізації сім'я відіграє вирішальну роль і лише $20 \%$ зазначили, що велике значення в процесі соціалізації відіграє особистість дитини, іiі друзі та школа. «Чи зустрічалися у вашій практиці такі випадки негативного впливу на підлітка?» - 75\% педагогів, переважно це були люди старшого віку (40-69 років), зазначили, що такі випадки неодноразово траплялися в їх практиці, 20\% респондентів зазначили, що такі випадки поодинокі і лише 5\% взагалі з цим не зустрічалися. На запитання: «Як ви можете охарактеризувати особистість таких підлітків, їхню поведінку», опитувані назвали такі найбільш поширені характеристики: зухвалість, неповага до інших, переконання, що їх всі осуджують і всі налаштовані до них вороже, іноді навпаки замкненість, небажання будь-що обговорювати щодо їх особистого життя. Основними причинами, які спонукують підлітків до залучення до комерційного сексу, на думку педагогів, є: неблагополучний клімат в сім’і, зловживання батьків алкоголем, коли дитина з раннього віку є самотньою, тобто, вона сама по собі і ніхто про неї не піклується, недостатнє матеріальне забезпечення, бажання стати дорослішими, на думку більшості перше місце посідає саме сімейне виховання підлітків. «Чи є актуальною проблема комерційного сексу серед підлітків і молоді в Україні?» - переважна більшість опитуваних (78\%) вважають, що такої проблеми в нашій державі не існує, 19\% респондентів вважають, що дане явище виникає лише в певних соціальних групах, але говорити про його актуальність $\epsilon$ не зовсім доцільно і лише $3 \%$ опитаних вважають дану проблему актуальною в 
наш час. На запитання «Чи проводите Ви профілактичну роботу серед підлітків на тему комерційного сексу та його шкідливих наслідків?» - $85 \%$ опитаних відповіли, що не бачать в цьому потреби, а $15 \%$ педагогів зазначили, що обговорюють $з$ учнями деякі аспекти даного запитання, усі педагоги, які проводять дані бесіди вказали що, вони сприяють налагодженню взаєморозуміння 3 учнями/ученицями і мають позитивний результат (рис.1).

\section{ні так}

\section{Чи проводите Ви профілактичну роботу серед підлітків на тему...}

Чи с актуальною проблема комерційного сексу серед...

Чи зустрічалися випадки негативного впливу на...

Чи впливає неблагополуччя сім'ї на соціалізацію підлітків?

Чи проводите заняття з учнями по статевому вихованню?

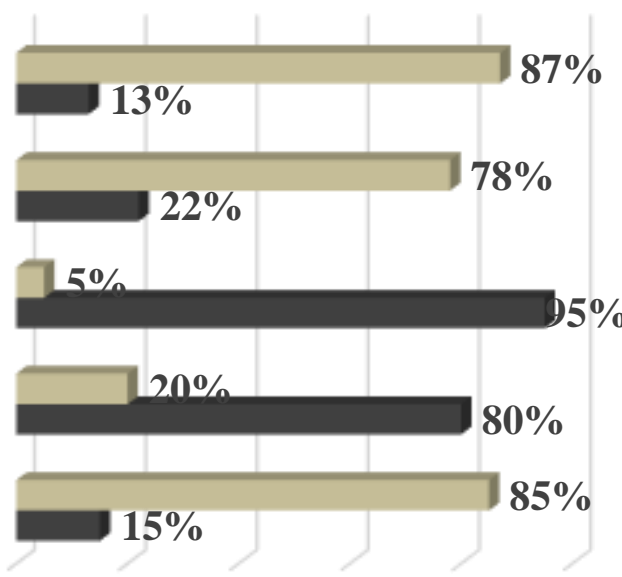

Рис. 1. Вплив школи на морально-статеве виховання підлітків.

Отже, в результаті проведення анкетування з'ясувалося що, більшість педагогів/педагогинь пов'язує поняття комериійного сексу з проституиією $i$ вважає, що воно є актуальним для дітей вуличі, лише 15\% опитаних зазначили, що ведуть бесіди зі своїми учнями/ученичями про дану проблему. Визначальним фактором у вихованні більшості педагогів є сім'я в якій виховується підліток.

Спостереження показали, що вчителям набагато легше розповісти дитині про шкідливість алкоголю, наркотиків, токсичних речовин, про кримінальну відповідальність за скоєння злочину, небезпеку ВІЛ/СНІДу ніж про статеве життя, проституцію та іï негативні наслідки. На жаль, ми ще не навчилися відверто говорити про це суспільне явище та його складні наслідки. Крім того у системі освіти не створено цільових програм націлених на попередження негативних соціальних явищ. Тому кожній дитині, не маючи у достатній кількості потрібної інформації, доводиться самостійно робити вибір між хорошим і поганим. Важливо допомогти молодій людині правильно вибрати життєві орієнтири, спрямувати іiі енергію на досягнення позитивних цілей (навчання, здобуття престижної професії тощо), сформувати уявлення про добро і зло, 
хороші і погані вчинки. На прикладах показати негативне ставлення більшості суспільства до пияцтва, наркоманії, секс-бізнесу.

3 метою визначення рівня довіри, обізнаності батьків щодо організації вільного часу дітей нами було проведене анкетування серед батьків досліджуваних підлітків . В анкетуванні взяли участь 50 осіб.

У результаті ми отримали наступні дані:

- 88\% учнівської молоді, незалежно від статі, легко розмовляють на теми, що хвилюють, саме з матір'ю;

- 65\% опитаних зазначили, що можуть легко обговорювати свої проблеми 3 батьком;

- дівчата складніше, порівняно $з$ хлопцями, довіряють свої проблеми батькам (58\% проти 73\% відповідно);

- 3 віком простежується тенденція до ускладнення обговорення молоддю особистих проблем з батьками;

- в сімейному колі проблеми і новини щодня або майже щодня обговорюють понад $60 \%$ опитаних.

Оскільки важливою складовою життєдіяльності особистості є їі соціальне оточення, анкета для батьків містила запитання про проведення вільного часу дітей.

Поінформованість батьків щодо життя дітей:

$70 \%$ батьків добре знає друзів своїх дітей;

$7 \%$ опитаних зазначили, що нічого не знають про друзів дітей;

$67 \%$ проінформовані на рахунок проведення дитиною часу після навчання;

3 дорослішанням дитини відсоток батьків, які взагалі нічого не знають, де буває дитина після навчання зростає $-27 \%$;

де зазвичай дитина буває ввечері знає - 66,5\% батьків;

майже третина батьків знають небагато про те, де дитина буває ввечері - 27\%;

відсоток батьків, добре обізнаних 3 проведення вільного часу становить 63,5\%;

третина батьків (33\%) небагато знають про те, як їхні діти проводять вільний час.

Крім того, батькам досліджуваних було запропоновано відповісти на наступні запитання: «На Вашу думку, комерційний секс - це» (рис.2) проституція - 65\% досліджуваних, секс за гроші - 20\% досліджуваних, секс як винагорода за певні матеріальні або соціальні блага $-15 \%$ осіб. 


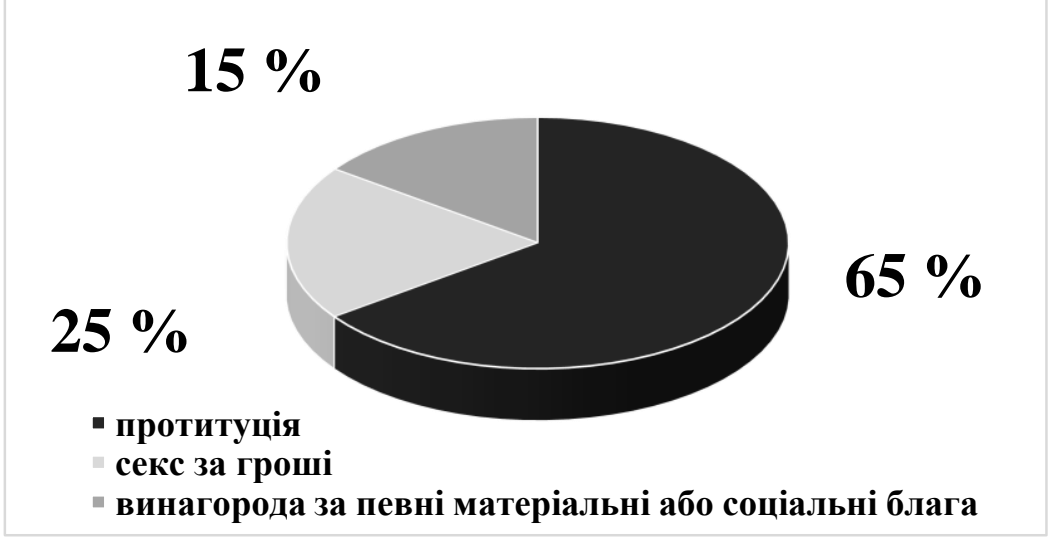

Рис. 2. «На Вашу думку, комериійний секс-ие...»

«Чи вважаєте Ви, що для підлітків і молоді в Україні проблема комерційного сексу є актуальною?», на що $82 \%$ респондентів дали заперечну відповідь, а $18 \%$ припустили існування даної проблеми серед дітей найбільш незахищених верств населення, або дітей позбавлених батьківського піклування.

Серед шляхів залучення підлітків до комерційного сексу найбільше опитаних вказали несприятливе соціальне оточення, бездоглядність дітей, необхідність самостійно заробляти кошти, наявність шкідливих звичок. На запитання «Чи $є$ ймовірність, що Ваша дитина може потрапити до таких «груп ризику»?» 90\% досліджуваних дали категорично заперечну відповідь, 10\% вказали, що можливо їхя дитина буде спілкуватися 3 такими підлітками, але сама не буде 3 цим пов'язана.

«Хто, на вашу думку, має займатися профілактикою залучення підлітків до комерційного сексу?» $60 \%$ батьків вважають, що це справа сім'ї, $26 \%$ опитуваних зазначили, що школа і сім'я мають діяти спільно, на думку $8 \%$ респондентів цим має займатися школа, $5 \%$ покладають це на спільну роботу школи, соціальних служб та молодіжних організацій, $1 \%$ досліджуваних вважає, що кожен підліток сам в змозі розібратися з цим питанням.

Слід зазначити, що в анкетуванні взяли участь 50 чоловік віком 35-54 роки, 3 них $74 \%$ жінки і $26 \%$ чоловіки, $84 \%$ з повних сімей, $16 \%$ - сім'ї неповні, $22 \%$ опитуваних має троє і більше дітей.

Отже, переважна більшість батьків (близько 67\%) знає друзів свойх дітей, де вони проводять час після уроків та ввечері. Проблема комериійного сексу серед неповнолітніх пов'язують з дітьми позбавленими батьківського піклування, а можливість причетності власних дітей ігнорують. 
На наступному етапі нами було проведене анкетування серед учнів/учениць 3 метою визначення рівня обізнаності підлітків щодо ризиків, якими загрожує залучення до комерційного сексу. Для цього нами була складена анкета i проведена з учнями/ученицями 8-10 класів.

Загальна кількість досліджуваних складає 100 осіб. Хлопців було 46 осіб (46\%), а дівчат - 54 (54\%).

Що стосується проблеми проституції, то ми поцікавилися у респондентів, чи знають вони, що таке комерційний секс. Досліджувані вважають, що комерційний секс - це (рис. 3): проституція - 90\%, шлях отримання матеріальних благ - 6\%, винагорода за матеріальні цінності - 4\%. На запитання: як ви ставитеся до комерційного сексу - більшість відповіли негативно, тільки 6 підлітків позитивно. Пояснювати свою відповідь вони відмовилися, що може свідчити про неусвідомленість даного вибору.

Якщо порівнювати відповіді батьків і підлітків, то бачимо, що більшість учасників дослідження зазначили, що, на їх думку, комерційний секс - це проституція.

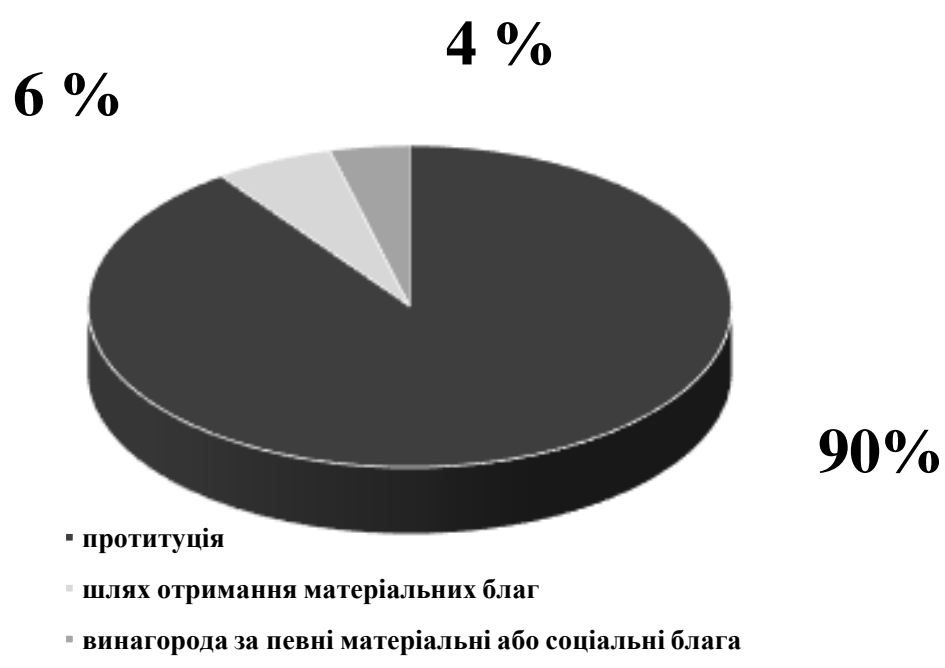

Рис. 3. «На Вашу думку, комериійний секс - ие...»

У нашому дослідженні ми поцікавилися про причини, які, на думку, респондентів, можуть сприяти залученню підлітків до комерційного сексу. На думку більшості респондентів, низький рівень доходів сім'ї може спричинити залучення підлітків до комерційного сексу.

3 точки зору опитуваних, комерційний секс може призвести до наступних негативних наслідків: деградація особистості, поширення проституції, небажання 
оволодіти іншими видами діяльності, небажана вагітність, має негативний вплив на подальшу долю людини яка цим займається, може негативно позначитися на стані здоров'я. Серед шляхів залучення до комерційного сексу називають: вживання наркотиків та людей, які їх реалізовують, знайомі, які залучені до надання такого виду послуг, несприятливе соціальне оточення.

Отже, на думку підлітків комериійний секс може призвести до деградаиії особистості, поширення проституції, матиме негативний вплив на подальшу долю особистості, 90\% опитуваних пов'язують дане поняття з проституцією.

Наступним кроком, ми намагалися визначити мотиваційно-ціннісну структуру особистості, переважаючий у досліджуваних тип цінностей, оскільки підлітковий вік $є$ сензитивним для розвитку мотиваційної сфери.

3 цією метою нами було використано морфологічний тест життєвих цінностей (МТЖЦ) В. Сопова, Л. Карпушина, Індекс життєвого стилю (Н. Дерев'янкін) і методику «Вихід із важких життєвих ситуацій» (Є. Варбан), оскільки це оптимальний, на нашу думку, діагностичний інструментарій, за допомогою якого можна визначити мотиваційно-ціннісну структуру особистості, переважаючу систему цінностей, а також домінуючий у підлітка спосіб вирішення життєвих проблем.

3 метою визначення мотиваційно-ціннісної структури особистості нами було проведено морфологічний тест життєвих цінностей (МТЖЦ). Ця методика включає в себе термінальні цінності, тобто відношення суб'єкта до явищ, об'єкта i суб'єкта, життєвого факту, і визнання його як важливого, який має життєву цінність.

Основним діагностичним конструктом МТЖЦ є термінальні цінності. Під терміном «цінність» ми розуміємо відношення суб'єкта до явища, життєвого факту, і визнання його як важливого.

Перелік життєвих цінностей включає:

1. Розвиток себе, пізнання своїх індивідуальних особливостей, постійний розвиток своїх навичок й інших особистісних характеристик.

2. Духовне задоволення, керівництво моральними принципами, перевага духовних потреб над матеріальними.

3. Креативність, реалізація своїх творчих можливостей, прагнення змінювати навколишню дійсність.

4. Активні соціальні контакти, встановлення сприятливих відносин у різних сферах соціальної взаємодії, розширення своїх міжособистісних зв'язків, реалізацію своєї соціальної ролі.

5. Власний престиж, завоювання свого визнання в суспільстві шляхом слідування певним соціальним вимогам.

6. Високе матеріальне становище, звертання до факторів матеріального благополуччя як головному сенсу існування.

7. Досягнення, постановка й вирішення певних життєвих завдань як головних життєвих факторів. 
8. Збереження власної індивідуальності, перевага власних думок, поглядів, переконань над загальноприйнятими, захист своєї неповторності й незалежності.

У конструкцію опитувальника входить шкала вірогідності ступеня бажання в людини соціального схвалення іï вчинків. Дана шкала розроблена на основі опитувальника американських психологів Дугласа П. Крауна й Девіда А. Марлоу; вона дозволяє виявити, по-перше, ступінь залежності людини від інших людей, по-друге, чи видає людина як відповідь бажані, схвалювані всіма суспільні цінності або свою індивідуальну (а не еталонну) систему життєвих цінностей. Чим вище результат, тим більше поведінка випробуваного (на вербальному рівні) відповідає схвалюваному зразку.

Як свідчать дані: 45\% опитаних (45 учнів/учениць) характеризуються невизначеною спрямованістю особистості, без вираженого направленого цілеспрямування, що є показником низьких значень 3 обох груп цінностей. У свою чергу духовно-моральні цінності переважають у 29\% (29 школярів) досліджуваних. Такі учні/учениці характеризуються спрямованістю до саморозвитку, духовного задоволення, виявлення креативності й прагнення до активних соціальних контактів. Натомість у 26\% досліджуваних (26 учнів/учениць) спостерігається переважання егоїстично престижних цінностей, про що свідчить спрямованість досягнення престижу, певні особисті досягнення, матеріальне становище, збереження індивідуальності.

Отже, в результаті проведення методики було встановлено щзо, у 45\% підлітків невизначена спрямованість особистості, без вираженого направленого цілеспрямування, у 29\% опитаних переважає спрямованість до саморозвитку, духовного задоволення, виявлення креативності й прагнення до активних соціальних контактів. Спрямованість досягнення престижу, певні особисті досягнення, матеріальне становище, збереження індивідуальності переважає у $26 \%$ досліджуваних.

Діагностика новоутворень у структурі особистості підлітка, детермінуючих соціально дезадаптовану поведінку неповнолітніх, $є$ необхідним компонентом психокоригуючої роботи $з$ дітьми, схильними до правопорушень. Це зумовлено тим, що з часом такі новоутворення стають складовою моделі поведінки дитини, звичним для неї засобом вирішення звичних життєвих проблем. У цьому випадку і виникає «непроникність» щодо виховних впливів, знання якої можливе тільки після подолання негативних особистісних новоутворень. 3 метою попередження або ранньої діагностики подібних новоутворень нами були використані методики «Індекс життєвого стилю» (Н. Дерев’янкін) і «Вихід із важких життєвих ситуацій» (Є. Варбан).

Метою методики є визначення переважаючого способу поведінки особистості у фруструючій ситуації.

В результаті ми отримали наступні дані: в 44\% досліджуваних у фруструючій ситуації переважає агресивна диспозиція (основна емоція - гнів (роздратування), основний захист - замінення, що передбачає управління гнівом агресією. За відсутності цього механізму така особистість безпосередньо виражала б свою 
агресивність, що призвело б до виникнення серйозних конфліктів. Цей механізм дозволяє направити реакцію агресії на безпечніший об'єкт), диспозиція психопатії (виражена потреба залишатися зовні в непідконтрольному стані) спостерігається у $20 \%$ досліджуваних, депресивна диспозиція (особистість такого типу весь час страждає через втрату уявного об'єкту і втрату самоповаги. Основна емоція печаль. Основний спосіб захисту - компенсація, направлена на уникнення відчуття депресіі) проявляється в 16\% підлітків, у 12\% спостерігається обсесивна диспозиція (прагнення контролювати. Захист - інтелектуалізація, раціоналізація і сублімація. Відчуження від інстинктів i емоцій. Сумлінність, охайність, прагнення дотримуватися середини, педантичність. Нездатність відгадувати людські емоції - прихована тривога втрати контролю), в $8 \%$ - пасивна диспозиція (інертність, пасивність, уникнення, відлюдництво, безініціативність, схильність бути залежним від кого-небудь. Страх і придушення (витіснення)).

Отже, в ході дослідження було встановлено що, у досліджуваної групи підлітків у фруструючих ситуаціях проявлясться агресія, виникають психопатії, депресії, тобто, психологічні стани за яких підлітки схильні до асочіальних вчинків.

Метою методики «Вихід 3 важких життєвих ситуацій» $\epsilon$ виявлення домінуючого у досліджуваних способу вирішення життєвих проблем.

Після обробки результатів нами були отримані наступні дані: $46 \%$ досліджуваних набрали від 16 до 26 балів це є свідченням того, що не завжди досліджуваний з достоїнством витримує удари долі, у 29\% від 27 до 36 балів, тобто досліджувані не можуть спокійно переживати неприємності і $25 \%$ підлітків отримали суму балів від 7 до 15 це свідчить про те, що досліджувані 3 легкістю сприймають неприємності, правильно оцінюючи те, що сталося й зберігають рівновагу.

Отже, в ході проведення даної методики було виявлено щэо, 25\% підлітків можуть адекватно оиінити ситуацію, що склалася $i$ досить спокійно переживають неприємності, 46\% досліджуваних часто зриваються в складних ситуаціях, а 29\% реагують на неприємні ситуаиії психологічно неадекватно.

\section{Висновки}

В результаті проведеного дослідження з'ясувалося, що більшість педагогів пов'язують поняття комерційного сексу з проституцією і вважають, що воно $\epsilon$ актуальним для дітей вулиці, однак лише $15 \%$ педагогів зазначили, що ведуть бесіди зі своїми учнями/ученицями щодо даної проблеми. Визначальним фактором у вихованні більшість педагогів вважають сім'ю, в якій виховується підліток.

Батьки досліджуваних підлітків проблему комерційного сексу серед неповнолітніх пов'язують 3 дітьми, позбавленими батьківського піклування, а можливість причетності власних дітей зазвичай ігнорують.

Актуальність проблеми профілактики залучення підлітків до комерційного сексу, з одного боку, та недостатня обізнаність учнів/учениць, педагогів та 
батьків $з$ основними аспектами цієї проблеми - 3 іншого боку, підтверджують необхідність удосконалення змісту, форм та методів профілактичних заходів, спрямованих на вирішення цієї проблеми.

Отже, негативне соціальне оточення, складне матеріальне становище, педагогічна занедбаність та інші чинники, які так чи інакше впливають на формування особистості дитини, передбачають застосування особливого підходу та використання нестандартних методів профілактичної роботи.

Таким чином, результати експерименту переконали нас у необхідності розроблення профілактичної програми, спрямованої на профілактику залучення підлітків до комерційного сексу та створенні необхідного профілактичного середовища у закладах загальної середньої освіти щодо організації соціальної профілактики залучення підлітків до комерційного сексу.

Загалом можна сказати, що методологічні прийоми і методи профілактики залучення підлітків до комерційного сексу виходять далеко за межі статевого виховання чи пропаганди здорового способу життя, це складна задача, яку потрібно вирішувати у комплексі, що включає зокрема: професійну орієнтацію, профілактику і виправлення асоціальної і антисуспільної поведінки, поширення медичних знань, встановлення дружніх відносин між вчителем і учнями та багато інших аспектів та напрямів педагогічної роботи.

\section{Література}

Балакірєва, О., Бондар, Т., Галустян, Ю. та ін. (2012). Секс-бізнес в Україні: спроба соціального аналізу. К.: Державний інститут сім’ї та молоді. 159 с.

Балакірєва, О., Бондар, Т., Сазонова, Я., Сакович, О. (2018). Підлітки груп ризику: оновлені оцінки. УІСД ім. О. Яременка та ЮНІСЕФ. Режим доступу: https://www.unicef.org/ukraine/media/581/file/risk_teens_HIV.pdf

Звєрєва, І. Д., Безпалько, О. В., Марченко, С. Я. та ін. (2004). Соціальна робота в Україні : навчальний посібник. К.: Центр навчальної літератури. 256 с.

Кушнірчук, О. Р. (2018). Соціально-педагогічна профілактика проституції неповнолітніх у школах-інтернатах. Нац. пед. ун-т ім. М. П. Драгоманова. 23 с.

Кушнірчук, О. Р. (2013). Поняття проституції: міжкатегоріальний аналіз. Междисциплинарные исследования в науке и образовании. № 2. Режим доступу: http://mino.esrae.ru/160-1271

Протопопов, А. О., Савельєва, Н. М. (2019). Проституція як соціальнопедагогічна проблема. За заг. ред. Н. М. Савельєвої. Полтава: Дивосвіт. 120 с.

Раделицька, I. I. (2019). Попередження сексуальної експлуатації дітей. Наукові здобутки студентів Інституту людини. № 2 (6). С. 23-28.

Шиделко, А. В. (2011) Проституція неповнолітніх як крайній прояв статевої деморалізації. Режим доступу: http://soctechjournal.kpu.zp.ua/archive/2011/50/54.pdf 


\section{SOCIAL PREVENTION INVOLVEMENT OF ADOLESCENTS IN COMMERCIAL SEX IN GENERAL SECONDARY EDUCATION INSTITUTIONS}

Viktoria Melnychuk, head of the sector of social and pedagogical work of the department of scientific and educational-methodical support of the content of out-ofschool education and educational work, State Scientific Institution «Institute for Modernization of Educational Content», Kyiv, Ukraine; m-viki@ukr.net

Abstract. The article considers the concept of commercial sex. Socio-psychological criteria are described, according to which it is possible to distinguish a "risk group" among adolescents who may be involved in commercial sex. It is noted that the involvement of adolescents in commercial sex is due to a large set of interrelated reasons, which determines the need for a comprehensive approach to social prevention of adolescent involvement in commercial sex. The organization of social prevention of involvement of teenagers in commercial sex in the conditions of general secondary education is considered. The results of a study on the awareness of participants in the educational process about the involvement of adolescents in commercial sex are described. It is noted that preventive work to prevent negative social phenomena, including prostitution, is established and carried out in educational institutions and in the family. It is proved that the negative social environment, difficult financial situation, pedagogical neglect and other factors that in one way or another affect the formation of the child's personality, involve the use of a special approach and the use of nonstandard methods of preventive work. The need to develop a prevention program aimed at preventing the involvement of adolescents in commercial sex. It is determined that the main preventive work to prevent negative social phenomena, including prostitution, is established and carried out in the educational institution and in the family. It is proved that methodological techniques and methods of prevention of adolescents' involvement in commercial sex should be addressed in a complex that includes: career guidance, prevention and correction of antisocial and antisocial behavior, dissemination of medical knowledge, establishing friendly relations between teacher and students and many other aspects and areas pedagogical work.

Keywords: commercial sex; teenager; sexual violence; child prostitution; social prevention; general secondary education institution; victim of violence. 


\section{References}

Balakireva, O., Bondar, T., Galustyan, Y. and others. (2012). Sex business in Ukraine: an attempt at social analysis. K .: State Institute of Family and Youth. 159 s. [in Ukrainian].

Balakireva, O., Bondar, T., Sazonova, J., Sakovich, O. (2018). Adolescents at risk: updated assessments. UISD them. O. Yaremenko and UNICEF. Access mode: https://www.unicef.org/ukraine/media/581/file/risk_teens_HIV.pdf [in Ukrainian].

Zvereva, I. D, Bezpalko, O. V, Marchenko, S. Ya. etc. (2004). Social work in Ukraine: a textbook. K .: Center for Educational Literature. 256 s. [in Ukrainian].

Kushnirchuk, O. R. (2018). Socio-pedagogical prevention of prostitution of minors in boarding schools. Nat. ped. Univ. MP Dragomanova. 23 s. [in Ukrainian].

Kushnirchuk, O. R. (2013). The concept of prostitution: intercategorical analysis. Interdisciplinary research in science and education. № 2. Access mode: http://mino.esrae.ru/160-1271 [in Ukrainian].

Protopopov, A. A, Savelieva, N. M. (2019). Prostitution as a socio-pedagogical problem. For the general ed. NM Savelyeva. - Poltava: Miracle World. 120 s. [in Ukrainian].

Radelitskaya, I. I. (2019). Prevention of sexual exploitation of children. Scientific achievements of students of the Institute of Man. № 2 (6). Pp. 23-28. [in Ukrainian].

Shidelko, A. V. (2011) Prostitution of minors as an extreme manifestation of sexual demoralization. Access mode: http://soctech-journal.kpu.zp.ua/archive/2011/50/54.pdf [in Ukrainian].

\section{Article history:}

Received: April 27, 2021

1st Revision: May 18, 2021

Accepted: May 30, 2021 